\title{
Fahr's Syndrome: A Patient with Idiopathic Hypoparathyroidy in the Emergency Department
}

\author{
Fahr Sendromu: Acil Serviste Idiyopatik Hipoparatiroidili Bir Hasta
}

Cem Ertan', Esra Karaman', Hakan Oğuztürk1, Dilek Ertan²

'İnönü Üniversitesi Tıp Fakültesi, Acil Tıp Anabilim Dalı, Malatya, Türkiye

²Özel Sevgi Tıp Merkezi, Radyoloji Kliniği, Malatya, Türkiye

\section{ABSTRACT}

Patients attending emergency departments (EDs) with nonspecific neurological symptoms have a wide range of differential diagnoses. In this case report, we present a female patient with episodic peripheral paresthaesia, who ended up with a diagnosis of Fahr's syndrome, a rare pathology characterised by bilateral striatopallydodental calcifications. A 78 year old female presented to our ED with numbness in the left arm and leg, and a history of four episodes of facial numbness which occurred during the previous day. Physical examination of the patient revealed no lateralising neurological deficits, but Chvostek's sign was (+).The only notable pathology of the patient arising from routine lab work was the Ca level of $\mathrm{Ca}^{++}(5.8 \mathrm{mg} / \mathrm{dL})$. A computed tomography scan of the brain showed bilateral calcifications in the basal ganglia and cerebellum. The patient was examined by a neurology and endocrinology consultant in the ED and hospitalised for hypocalcaemia replacement and further diagnostic endocrinology investigations related to Fahr's syndrome. In patients with acute nonspecific neuropsychiatric symptoms, especially in the case of $\mathrm{Ca}^{++}$metabolism disorders, Fahr's syndrome should be a part of differential diagnosis, and diagnostic investigations performed in the ED should include this syndrome.

Keywords: Fahr's syndrome, emergency department, hypocalcaemia, hypoparathyroidy

Received: 09.08.2011 Accepted: 13.11.2011

\section{ÖZET}

Acil servise nonspesifik nörolojik semptomlarla başvuran hastalarda oldukça geniş bir nörolojik ve metabolik bir ön tanı yelpazesi mevcuttur. Burada servisimize epizodik periferik parestezik şikayetlerle acil servise başvuran ve bilateral striyatopallidodental kalsifikasyonla karakterize nadir bir klinik durum olan Fahr Sendromu tanısıyla sonlanan bir hastayı sunmayı amaçladık. Yetmiş sekiz yaşında bayan hasta acil servise sol kol ve bacakta uyuşma ve bir gün öncesinde 4 kez ataklar şeklinde olan yüzde uyuşma şikayetiyle başvurdu. Nörolojik muayenesinde lateral motor defisiti olmayan hastanın Chvostek testi (+) bulundu. Diğer sistem muayenelerinde ek herhangi bir patoloji saptanmadı. Serum biyokimyasında $\mathrm{Ca}^{++}$ düşüklüğü (5.8 mg/dL) tespit edilen hastanın nörolojik şikayetlerinin ayırıcı tanısı için çekilen beyin BT'sinde bazal ganglion ve serebellumda bilateral kalsifikasyonlar saptandı. Nöroloji ve Endokrinoloji bölümleri ile konsulte edilen hastada mevcut bulgularla Fahr Sendromu düşünüldü. Nonspesifik akut nöropsikiyatrik şikayetlerle acil servise başvuran hastalarda, özellikle $\mathrm{Ca}^{++}$metabolizması ile ilgili patoloji varlığında Fahr sendromu da akla getirilmeli ve ileri tetkikler bu yönde planlanmalıdır.

Anahtar Kelimeler: Fahr sendromu, acil servis, hipokalsemi, hipoparatiroidi

Geliş Tarihi: 09.08.2011 Kabul Tarihi: 13.11.2011

\section{Giriş}

Acil servise kişilik değişiklikleri, mental ve zihinsel işlevlerde bozulma, demans ve duygu-durum bozukluklarının yanı sıra rijidite, hipokinezi, tremor ve ataksi gibi hareket bozukluklarını da içerebilen nörolojik semptomlarla başvuran hastalarda oldukça geniş bir nörolojik ve metabolik bir ön tanı yelpazesi mevcuttur. Menenjit, ensefalit, iskemik inme, demans gibi hastalıkların yanı sıra daha nadir görülen sendromik tablolar da bu çerçevede düşünülmelidir.

Fahr sendromu; bilateral striyatopallidodental kalsifikasyonla seyreden nadir bir klinik durumdur (1). Bu kalsifikasyonların nasıl oluştuğu kesin olarak bilinmemekle beraber enfeksiyon, metabolik ve genetik bozukluklarla ilişkili olabileceği belirtilmektedir $(2,3)$. 
Illk olarak 1930 yılında tanımlanan bu sendrom hipoparatiroidizm, psödohipoparatiroidizm veya hiperparatiroidizm nedeniyle ortaya çıkabilir (4-6).

Yazımızda epizodik periferik parestezik şikayetlerle acil servise başvuran ve bilateral striyatopallidodental kalsifikasyonla karakterize nadir bir klinik durum olan Fahr Sendromu tanısıyla sonlanan bir hastayı sunmayı amaçladık.

\section{Olgu Sunumu}

Yetmiş sekiz yaşında bayan hasta acil servise sol kol ve bacakta uyuşma ve bir gün öncesinde 4 kez ataklar şeklinde olan yüzde uyuşma şikayetiyle başvurdu. İlk değerlendirimesinde genel durumu iyi, bilinci açık, oryante ve koopere olan hastanın, başvuru anında kan basıncı 125/88 mm Hg, nabız sayısı 82 atım/dk, solunum sayısı 16/dk ve $\mathrm{SPO}_{2}$ değeri 98 idi. Acil serviste değerlendirilen hastanın nörolojik muayenesinde Chvostek testi (+) bulundu. Bunun dışında lateralizan motor veya duyu defisiti saptnanamayan hastanın, diğer sistem muayenelerinde de ek herhangi bir patoloji saptanmadı.

Özgeçmişinde geçirilmiş iskemik inme ve osteoporoz dışında eşlik eden aktif veya geçirilmiş bir hastalık mevcut değildi. Hastanın soygeçmişi sorgulandığında ek bir hastalık bilgisine ulaşılamadı.

Tetkikleri için kan örnekleri alınan hastanın tam kan sayımı normal olarak değerlendirilirken, serum biyokimyasında hipokalsemi ve hiperfosfatemi tespit edildi. Hastanın serum kalsiyum $\left(\mathrm{Ca}^{++}\right)$değeri $5.8 \mathrm{mg} / \mathrm{dL}$ (8.4-10.8 mg/dL), serum fosfor ( $\left.P^{-}\right)$değeri ise $6.2 \mathrm{mg} / \mathrm{dL}$ (2.3-4.7 mg/ $\mathrm{dL}$ ) olarak saptandı. Bu iki değer dışında başka bir patoloji saptanmadı.

Hastanın nörolojik şikayetlerinin ayırıcı tanısı için çekilen bilgisayarlı beyin tomografisinde (BBT) bazal ganglion ve serebellum yerleşimli

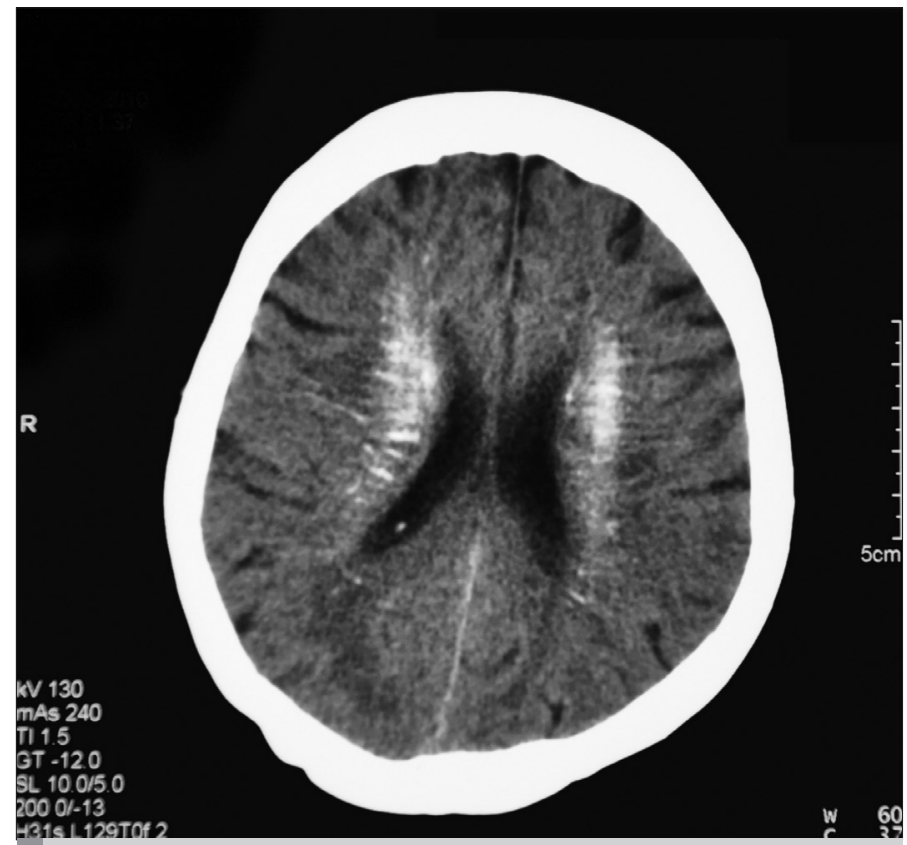

Resim 1. Periventriküler bölgede simetrik yerleşimli kalsifikasyonlar bilateral kalsifikasyonlar saptandı (Resim 1, 2). Nörolojik semptomları ve BBT bulguları nedeniyle Nöroloji bölümüyle ve semptomatik hipokalsemisi nedeniyle Endokrinoloji bölümleri ile konsulte edilen hastada mevcut bulgularla Fahr sendromu düşünüldü. Nöroloji kliniğince acil nöropatoloji düşünülmeyen hasta, kalsiyum düşüklüğü nedeniyle replasman ve ileri tetkik amaçlı Endokrinoloji servisine yatırıldı. Yapılan tetkiklerinde hipoparathormonemi (PTH $<3$ pg/mL; 10-75 pg/mL) tespit edilen hastaya yattığı klinikde IV ve oral kalsiyum replasman tedavisi uygulandı. Yatışının beşinci gününde kalsiyum değerinin 9.8 mg/ $\mathrm{dL}$ düzeyine yükselmesi ve fosfor değerinin de $4.9 \mathrm{mg} / \mathrm{dL}$ düzeyine gerilemesi üzerine poliklinikten takip edilmek üzere taburcu edildi.

\section{Tartışma}

Sıklıkla Fahr sendromundan sorumlu element olan kalsiyum, kapillerler, arteriyoller, küçük venler ve perivasküler alanlarda birikirek kraniyal mikro damarlarda obliterasyon, damar çevresinde nöronal dejenerasyon ve gliyozise sebep olur (4, 7-9).

Acil servise nonspesifik ve muhtemel nörolojik kaynaklı şikayetlerle başvuran hastamıza çekilen BBT'de, bilateral serebellum, kaudat nükleuslar, bazal bangliyonlar ve periventriküler alanlarda simetrik yerleşimli kalsifikasyonlar saptandı. Bu bulgu hastada Fahr sendromu tanısını düşündürmüştür $(1,4)$.

Fahr sendromu dört grup altinda toplanabilen etyolojik etmenlerle birlikte seyreder: birinci grupta, kalsiyum metabolizma degisiklikleri, hipoparatiroidizm, psödohipoparatiroidizm, veya hiperparatiroidizm yer alır; ikinci grubu konjenital dejeneratif gelişim anomalileri; üçüncü grubu sistemik hastaliklar ve geçirilmiş enflamatuvar olaylar oluştururken, dördüncü grupta ise toksik ve anoksik etkilenmelere ikincil tutulum bulunur (10)

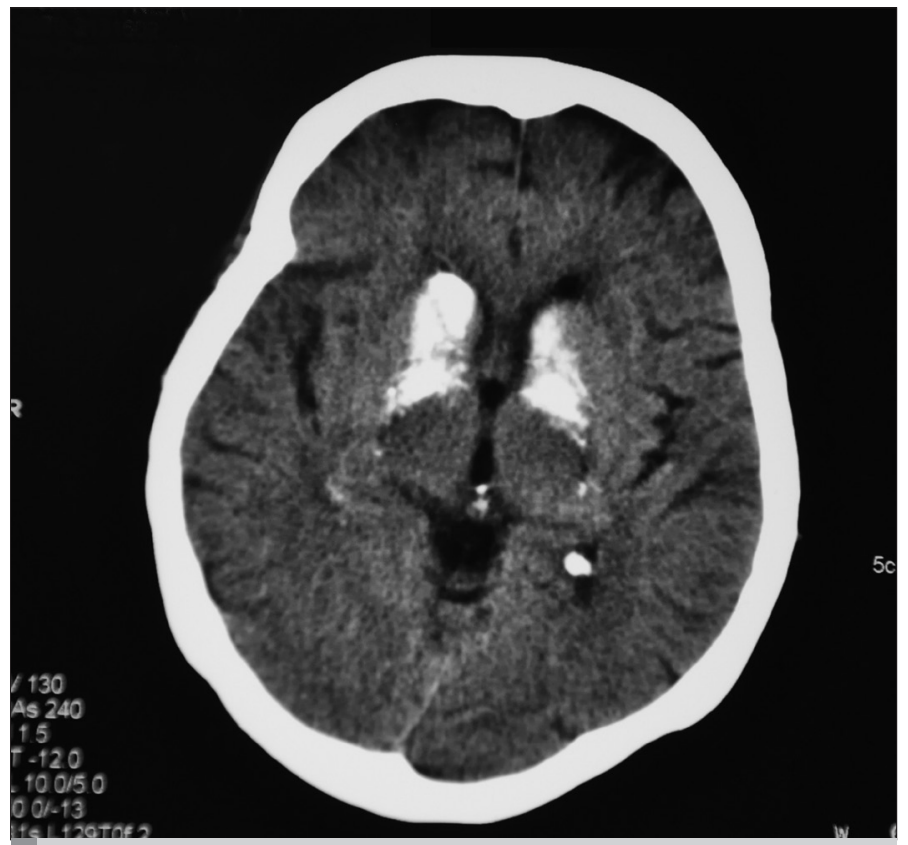

Resim 2. Kaudat nükleus ve globus pallidusda bilateral simetrik yerleşimli kalsifikasyonlar 
Sekonder bilateral striyatopallidodental kalsifikasyonda en sık saptanan etiyolojik neden hipoparatiroidizm ve hipokalsemidir (4). Olgumuzda da, literatürle uyumlu olarak ilk değerlendirmesinde hipokalsemi kliniğiyle uyumlu fizik muayene bulguları, muayene bulgularını destekler nitelikte laboratuar sonuçları ve nihayetinde yatışı esnasında aldığı hipoparatiroidizm tanısı mevcuttu. Hipoparatiroidizmin ciddiyeti ile serebral kalsifikasyon derecesi arasında bir ilişki bulunmamaktadır. Hipokalseminin süresi uzadıkça, bazal gangliyonlarda kalsifikasyona rastlanma sıklığı artar. Kalsiyum ve vitamin D'nin yerine konulması metabolik anormalliği düzeltir ve klinik progresyonu yavaşlatır $(9,11)$.

Hipoparatiroidizm nörolojik açıdan semptomatik veya latent tetani, nöbetler ve bilateral striyatopallidodental kalsifikasyonda görülen klinik tablolarla seyredebilir; nöbetler, her yaşta görülebilir ve genellikle jeneralize tonik klonik karakterdedir (12). Ancak olgumuzda hipoparatiroidizm'e sekonder bulgulardan hiçbirisine rastlanmamış, hastalık hafif bir seyirle ilerlemiş ve ağır klinik tablo ortaya çıkmadan hastaya tanı konulabilmiştir.

Olgumuz, klinik tablo, laboratuvar, görüntüleme sonuçları ve tedaviye yanıtı ile idiyopatik hipoparatiroidi ve Fahr sendromu olarak değerlendirildi. Fahr sendromunda, semptomlar çeşitlilik göstermekte olup, semptomatik olanların tedavi edilebilir alt gruplarının hızla saptanması hasta için hayati önem taşır.

\section{Sonuç}

Nonspesifik akut nöropsikiyatrik şikayetlerle acil servise başvuran hastalarda, özellikle kalsiyum metabolizması ile ilgili patoloji varlığında Fahr sendromu da akla getirilmeli ve ileri tetkikler bu yönde planlanmalıdır.

\section{Çıkar Çatışması}

Yazarlar herhangi bir çıkar çatışması bildirmemişlerdir.

\section{Kaynaklar}

1. Açıkgöz NP, Kamışlı Ö, Altınayar S, Özcan C, Fahr Sendromu Olguları. Parkinson Hast. Hareket Boz. Der 2007; 10: 41-5.

2. Harrington MG, Macpherson P, Mclntosh WB, Alam BF, Bone I. The significance of the incidental finding of basal ganglia calcification on computed tomography. J Neurol Neurosurg Psychiatry 1981; 44: 1168-70. [Crossref]

3. Fenelon G, Gray F, Paillard F, Thibierge M, Mahieux F, Guillani A. A prospective study of patients with CT detected pallidal calcifications. J Neurol Neurosur Psychiatry 1993; 56: 622-5. [Crossref]

4. Kökeş Ü, Hız F, Özden DL, Çınar M. Psödohipoparatiroidinin yol açı̆ı̆ı bir Fahr sendromu olgusu. Parkinson Hast Hareket Boz Der 2009; 12: 18-24.

5. Windeck R, Menken U, Benker G, Reinwein D. Basal ganglia calcification in pseudohypoparathyroidism type II. Clin Endocrinol 1981; 15: 57-63. [Crossref]

6. Beall SS, Patent BM. Abnormal systemic metabolism of iron, porphyrin and calcium in Fahr"s syndrome. Ann Neurol 1989; 26: 569-75. [Crossref]

7. Manyam BV. What is and what is not 'Fahr's disease'. Parkinsonism Relat Disord 2005; 11: 73-80. [Crossref]

8. Hanağası H, Hanağası F, Bilgiç B, Gürvit H, Yazıcı J, Emre M. Bilateral striopallidodentat kalsinosis'in klinik spektrumu. Türk Nöroloji Dergisi 2004 5: 430-7.

9. Ramonet $\mathrm{D}$, de Yebra L. Similar calcification process in acute and chronic human brain pathologies. J Neurosci Res 2006; 83: 147-56. [Crossref]

10. Morgante L, Vita G. Di Perri R. Fahr's syndrome: local inflammatory factors in the pathogenesis of calcification. J Neurol 1986; 233: 19-22. [Crossref]

11. Karimi M, Habibzadeh F. Hypoparathyroidism with extensive intracerebral calcification in patients with beta-thalassemia major. J Pediatr Endocrinol Metab 2003; 16: 883-6. [Crossref]

12. Paprocka J, Jamroz E. Neurological picture and $1 \mathrm{H}$ MRS in 4 children with hypoparathyroidism. Przegl Lek 2005; 62: 680-4. 